\title{
Prosthecomicrobium hirschii, a New Species in a Redefined Genus
}

\author{
JAMES T. STALEY
}

\author{
Department of Microbiology and Immunology SC-42, University of Washington, Seattle, Washington 98195
}

\begin{abstract}
A new species of Prosthecomicrobium, Prosthecomicrobium hirschii (type strain, ATCC 27832), is named in honor of Peter Hirsch. The range of cell morphology of this new species overlaps that of species in the genera Prosthecomicrobium and Ancalomicrobium. Populations of $P$. hirschii contain some cells with short appendages, like cells of members of the genus Prosthecomicrobium. However, cells that have long appendages characteristic of the genus Ancalomicrobium are also found in the same cultures. Motile cells have single polar to subpolar flagella. Gas vacuoles have not been detected. Either short- or longappendaged cells can serve as mother cells in bud formation. Slide cultures indicate that a cell of a particular morphological type continues to divide to produce that same morphological type for several generations. The factor(s) that determines which cell type is produced is not presently understood. A variety of organic carbon sources, including formate, methanol, and ethanol, can be used for growth. The generic description is modified to include a greater variety of prosthecal types and the budding form of division, which is a property of all previously described species and the new species of Prosthecomicrobium emend.
\end{abstract}

The prosthecomicrobia are a group of multiply appendaged, heterotrophic bacteria comprising the three genera Prosthecomicrobium, Ancalomicrobium, and Stella. Morphological criteria have been used to distinguish among these three genera. Thus, Prosthecomicrobium contains several species with 10 to 30 prosthecae that are typically short (i.e., $<2.0 \mu \mathrm{m}$ long) and conical and extend from all locations on the rod-shaped cells. In contrast, the single species of the genus Ancalomicrobium, Ancalomicrobium adetum, has fewer prosthecae (normally eight or fewer) that are cylindrical and typically about $3.0 \mu \mathrm{m}$ long. Stella humosa is distinctly different from the members of the other genera because its two to seven prosthecae all lie in one plane.

A collection of seven new isolates of prosthecomicrobia was assembled for this investigation. These strains, which appear to be very similar to one another, have some features that are characteristic of the genus Prosthecomicrobium and other features that are associated with the genus Ancalomicrobium. A new species, Prosthecomicrobium hirschii, is proposed to accommodate this new bacterial group.

\section{MATERIALS AND METHODS}

Strains and conditions of growth. The seven strains used in this study were obtained from a variety of freshwater sources in the United States (Table 1). Most were isolated from dilute peptone $(0,01 \%)$ enrichment cultures by streaking plates of MMB medium when phase-microscopic examination of enrichment cultures indicated that they were present (8). MMB medium contains (per liter) $0.15 \mathrm{~g}$ of peptone, $0.15 \mathrm{~g}$ of yeast extract, $1.0 \mathrm{~g}$ of glucose, $0.25 \mathrm{~g}$ of ammonium sulfate, $20 \mathrm{ml}$ of Hutner modified salts solution, $10 \mathrm{ml}$ of vitamin solution, $15.0 \mathrm{~g}$ of agar, and distilled water to volume (8). Slide cultures were used to follow the developmental cycles. Air was included in the slide cultures by reducing the agar area to approximately one-half the diameter of the cover slip before sealing the cover slip with Vaspar. Slide cultures were incubated at room temperature on MMB medium. Photomicrographs were taken at periodic intervals with a Zeiss Ultraphot microscope.

Carbon source utilization was determined in MMB medium prepared without glucose (8). The carbon sources were added to final concentrations of $0.1 \%$ (wt/vol) after each was autoclaved separately at reduced pressure and time (6). Methanol and ethanol were added directly from 95 or $99 \%$ solutions. The optical densities of cultures were determined with a Spectronic 20 colorimeter at a wavelength of $560 \mathrm{~nm}$. Utilization of a carbon source was interpreted as positive if the optical density was more than $20 \%$ higher than the mean value of five controls that did not receive a test carbon source. Vitamin requirements were determined by the single-deletion technique (5). Maximum and minimum growth temperatures were tested on an aluminum gradient block (3).

Electron microscopy. Cell suspensions from actively growing cultures were placed on Formvar-coated 200-mesh copper grids for about $1 \mathrm{~min}$. Excess moisture was absorbed with bibulous paper, and the preparation was stained with $1 \%$ phosphotungstic acid $(\mathrm{pH} 6.8)$. The grids were then examined with an AEI EM6B electron microscope at $60 \mathrm{kV}$.

\section{RESULTS}

Cell and colony morphology. The cells of $P$. hirschii are short rods that measure 0.8 to 1.2 by 1.0 to $2.0 \mu \mathrm{m}$. The single most distinctive feature of the strains of $P$. hirschii is that two morphologically different cell types are produced; one cell type has numerous short $(<1.0-\mu \mathrm{m})$ conical prosthecae, whereas the other cell type has long $(>2.0-\mu \mathrm{m})$ cylindrical prosthecae (Fig. 1). The short-appendaged cells are similar to the cells of Prosthecomicrobium spp., and the cells with the long appendages resemble the cells of $A$. adetum. Also, some cells have a mixture of short and long appendages (Fig. 2). All strains of $P$. hirschii are motile by single polar to subpolar flagella. Most motile cells have short appendages, although motile cells with one or more long appendages also occur (Fig. 2).

The colonies are circular with entire margins, umbonate elevations, and light pink pigmentation.

Cell division. Slide cultures were used to follow the process of cell division (Fig. 3 and 4). Results from these experiments indicated that the cells divide by budding $(7,9)$. Furthermore, any given cell morphology (i.e., either a shortor long-appendaged mother cell) could give rise to a clone of either cell morphology. Thus, clones developing from a longappendaged mother cell resulted in short-appendaged daughter cells or in long-appendaged daughter cells (Fig. 3). Likewise, a short-appendaged mother cell gave rise to either 
TABLE 1. Strains and sources of $P$. hirschii and other prosthecomicrobia

\begin{tabular}{|c|c|c|c|c|}
\hline Species & Strain & ATCC no. & Source (contributor) & $\begin{array}{c}\text { Guanine- } \\
\text { plus-cytosine } \\
\text { content (mol } \\
\%)^{a}\end{array}$ \\
\hline \multirow[t]{7}{*}{ P. hirschii } & 6 & 27827 & Red Cedar River, E. Lansing, Mich. & 67.9 \\
\hline & 7 & 27828 & $\begin{array}{l}\text { Temporary pond, Ann Arbor, Mich. } \\
\text { (John Babincak) }\end{array}$ & 69.9 \\
\hline & 10 & 27829 & $\begin{array}{l}\text { Wintergreen Lake, Hickory Cor- } \\
\text { ners, Mich. }\end{array}$ & 68.9 \\
\hline & 11 & 27830 & $\begin{array}{l}\text { Kellogg Forest Pond, Hickory Cor- } \\
\text { ners, Mich. }\end{array}$ & 68.9 \\
\hline & 12 & 27831 & Bolin Creek, Chapel Hill, N.C. & 68.9 \\
\hline & 15 & $\begin{array}{l}\text { Not depos- } \\
\text { ited }\end{array}$ & $\begin{array}{l}\text { Muskrat (Botany) Pond, Chapel } \\
\text { Hill, N.C. }\end{array}$ & 68.9 \\
\hline & $16^{\mathrm{T}}$ & $27832^{\mathrm{T}}$ & $\begin{array}{l}\text { Muskrat (Botany) Pond, Chapel } \\
\text { Hill, N.C. }\end{array}$ & 68.9 \\
\hline P. enhydrum & 9 & 23634 & Putah Creek, Davis, Calif. & 65.8 \\
\hline P. pneumaticum & $3^{\mathrm{T}}$ & $23633^{\mathrm{T}}$ & Putah Creek, Davis, Calif. & 69.4 \\
\hline$P$. litoralum & $524-16^{\mathrm{T}}$ & $35022^{\mathrm{T}}$ & Puget Sound, Wash. (J. Bauld) & 67.0 \\
\hline \multirow[t]{2}{*}{ A. adetum } & $8^{\mathrm{T}}$ & $23632^{\mathrm{T}}$ & Putah Creek, Davis, Calif. & 70.4 \\
\hline & 18 & 27834 & $\begin{array}{l}\text { Pulpmill oxidation pond, Everett, } \\
\text { Wash. (Patricia Stanley) }\end{array}$ & 71.4 \\
\hline
\end{tabular}

"Data from references 3 and 9.

a short-appendaged daughter cell or a long-appendaged daughter cell (Fig. 3 and 4). Despite this ability to switch from one cell type to another in one generation, once a particular cell type was produced, it persisted for several generations. Moreover, it appears that when a cell undergoes its developmental process and matures sufficiently to begin producing a daughter cell, its morphology is set for life (Fig. 3 and 4). This phenonmenon was not studied sufficiently for definitive verification, however.

Cell division of $P$. hirschii was compared with cell division of strains of Prosthecomicrobium enhydrum and Prosthecomicrobium pneumaticum; close examination of dividing cells indicated that the latter two species also divide by budding (Fig. 5).

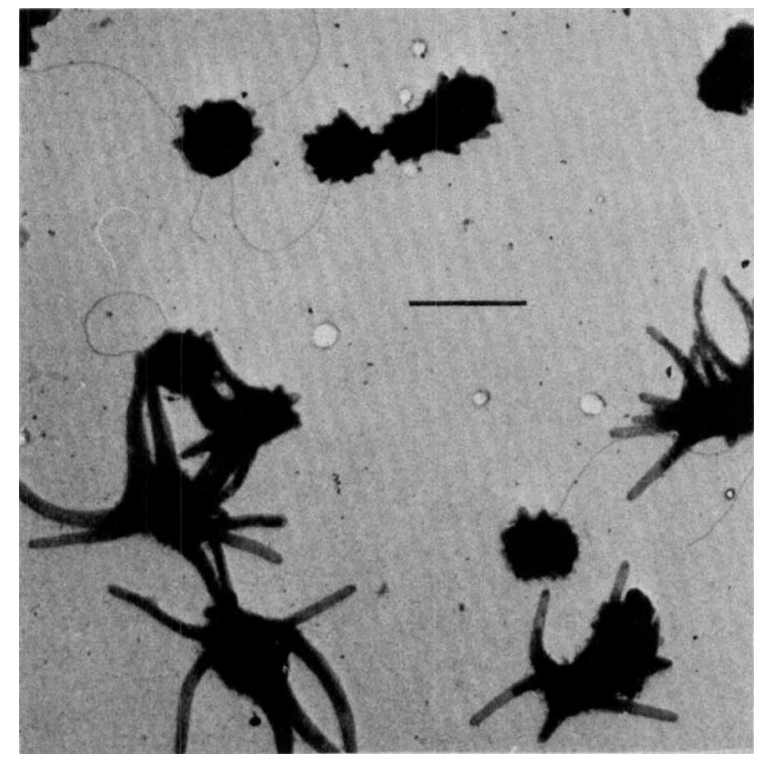

FIG. 1. Electron micrograph of strain 7. Note that some cells have short conical appendages, whereas others have long tubular appendages. $\mathrm{Bar}=2.0 \mu \mathrm{m}$.
Nutrition and physiology. $P$. hirschii used a variety of carbon sources for growth (Table 2). All pentoses and hexoses tested for growth were utilized by the $P$. hirschii strains, as well as by the other strains used for comparison. Unlike the two $A$. adetum strains tested and the other species of Prosthecomicrobium, $P$. hirschii used none of the disaccharides as a carbon source. Neither of the trisaccharides tested was used by the new species. Of the two deoxy sugars tested, fructose was used by all strains, but in contrast to all of the other strains tested, none of the strains of the new species used rhamnose. Both methanol and ethanol were used by the $P$. hirschii strains, although neither of these alcohols was used by the other strains tested. Glycerol was used by all strains, whereas mannitol, sorbitol,

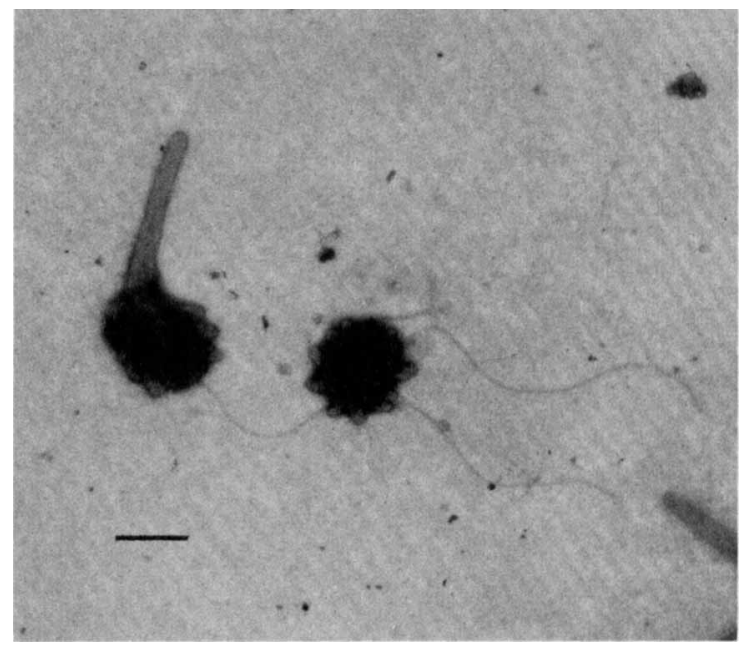

FIG. 2. Electron micrograph of negatively stained cells of strain 10. Note that one cell has both short and long prosthecae. The flagellum of the cell with the single long appendage appears to emanate from the pole. The flagellum from the short-appendaged cell is broken. Bar $=1.0 \mu \mathrm{m}$. 


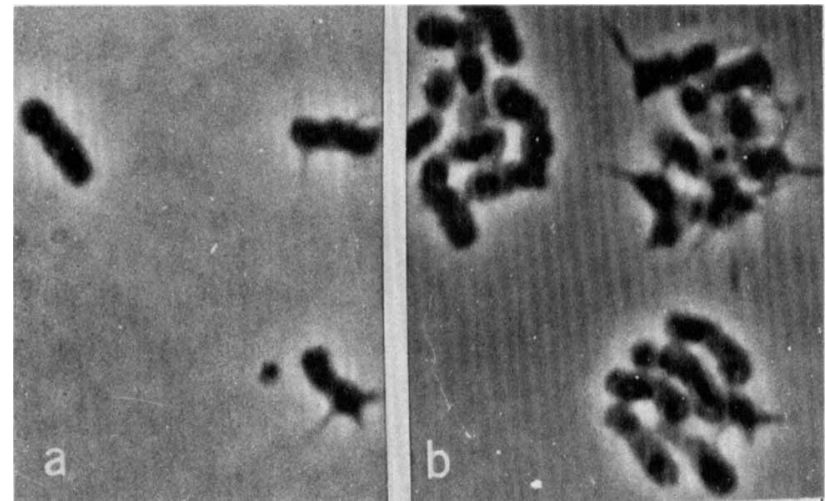

FIG. 3. Slide culture development of strain 6. Note that the short-appendaged upper left cell in (a) divides to give rise to a clone of short-appendaged cells (b). The long-appendaged cell in the upper right divides to give rise to a clone of long-appendaged cells. In contrast, the long-appendaged cell in the lower right divides to produce a clone of short-appendaged cells.

and inositol were not used by the new species. All of the fatty acids tested were used by $P$. hirschii strains, but formate and caproate were not used by any other species.

Thiamine, pantothenate, nicotinic acid, and biotin were required by all strains of $P$. hirschii tested.

All strains of $P$. hirschii grew as mesophiles over a temperature range of 9 to $40^{\circ} \mathrm{C}$ during an incubation period of up to 30 days.

Strains of $P$. hirschii grew as obligate aerobes. Growth occurred only aerobically in Hugh-Leifson tubes (2), and acid was produced from glucose. Growth did not occur in BBL GasPak containers on MMB medium. The strains tested were catalase and oxidase positive.

\section{DISCUSSION}

There are a number of features that make $P$. hirschii different from previously described species of Prosthecomi- crobium and Ancalomicrobium. As a motile, non-gas-vacuolate bacterium with short as well as long appendages, it differs markedly from $A$. adetum. Because it commonly produces long appendages, it differs from previously described species of Prosthecomicrobium. These morphological features are consistent with physiological features that permit a differentiation of the new species from previously described species of both genera. Finally, deoxyribonucleic acid hybridization studies support the establishment of a new species (4); homology was not detected between the type strains of $P$. enhydrum, $P$. pneumaticum, and $A$. adetum and the new species, whereas all of the strains of the new species included in the investigation showed a high degree of homology $(>85 \%)$ to strain $16^{\mathrm{T}}$ ( $\mathrm{T}=$ type strain). The more recently described species of Prosthecomicrobium, Prosthecomicrobium litoralum (1) and Prosthecomicrobium polyspheroides (11), are both short-appendaged organisms

Perhaps the major question to be considered in the proposal of a new species is, in which genus should the new species be placed? Although one could argue for inclusion of this new species in either Prosthecomicrobium or Ancalomicrobium, I propose to place it in the genus Prosthecomicrobium for the following reasons. First, it is a nonfermentative, obligate aerobe, clearly different from $A$. adetum. Second, unlike $A$. adetum, it is motile and non-gas vacuolate. Third, although deoxyribonucleic acid hybridization indicates that it is clearly different from all other species of Prosthecomicrobium and Ancalomicrobium, the deoxyribonucleic acid base composition (guanine-plus-cytosine) values lie within the range of the values for the species of Prosthecomicrobium and somewhat below the value for A. adetum.

$P$. hirschii is clearly a budding bacterium. Originally, the genus Prosthecomicrobium was distinguished from Ancalomicrobium by cell division differences. $A$. adetum divided by budding, but $\boldsymbol{P}$. enhydrum and $\boldsymbol{P}$. pneumaticum were described as dividing by binary transverse fission. However, a careful re-examination of slide cultures has revealed that Prosthecomicrobium spp. do divide by budding (Fig. 5). For

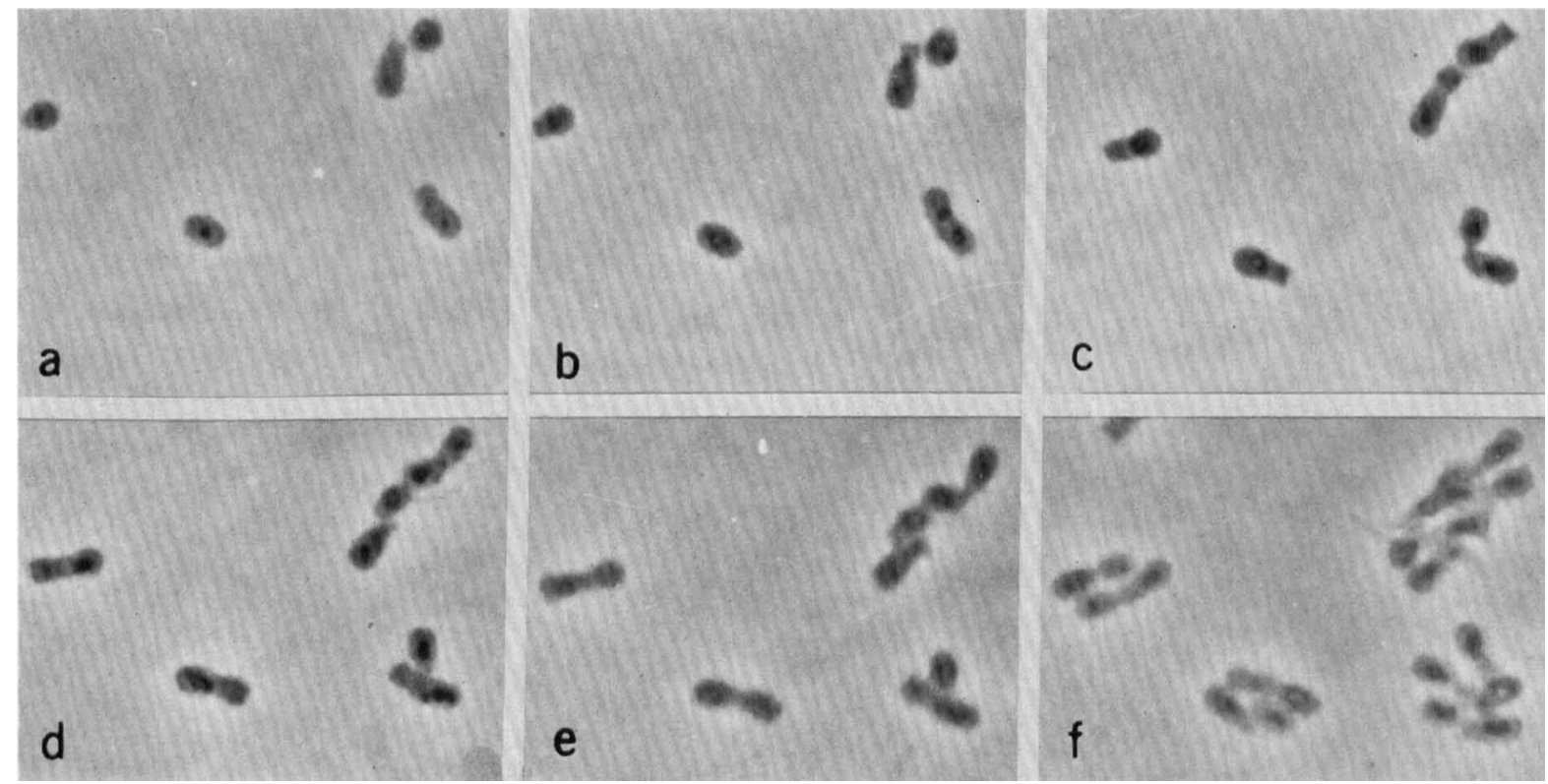

FIG: 4. Slide culture development of strain 7. Although all of the initial cells in (a) of this slide culture are short-appendaged, one cell divides to produce long-appendaged progeny within its clone. 


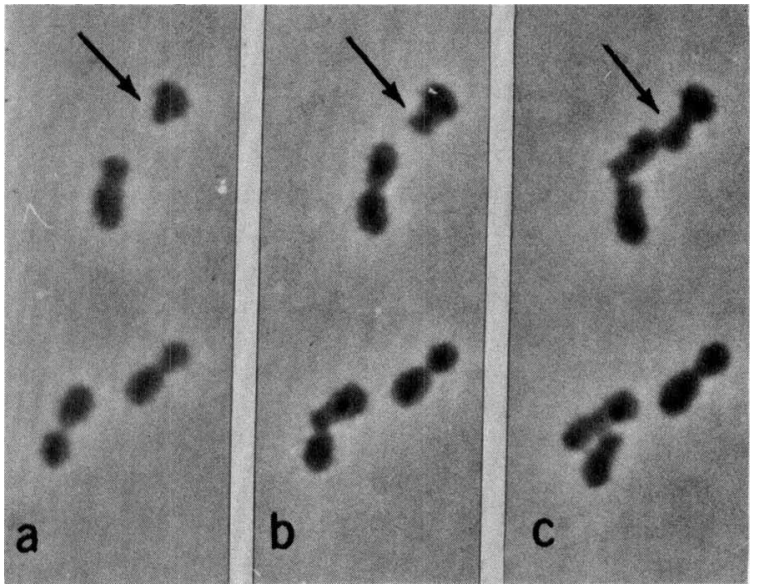

FIG. 5. Slide culture of a strain of $P$. enhydrum. Note the bud (arrow) that develops on one of the cells.

this reason and others introduced by the new species $P$. hirschii, the redescription of Prosthecomicrobium given below is proposed.

Genus Prosthecomicrobium (Staley 1968, 1940) emend. Unicellular, gram-negative bacteria that produce numerous prosthecae extending in all directions from the cell surface. All species produce prosthecae that are less than $2 \mu \mathrm{m}$ long and conical in shape, each tapering distally from the cell toward a blunt tip. Longer, cylindrical prosthecae are also produced by some species. Cells divide by budding. Motile species produce single polar to subpolar flagella. One species is known to be gas vacuolate.

Chemoorganotrophic. Nonfermentative. Aerobic. Found in freshwater, salt water, and soils.

The guanine-plus-cytosine contents of the deoxyribonucleic acids range from 65 to $70 \mathrm{~mol} \%$ (buoyant density method) for the strains that have been tested.

Type species: Prosthecomicrobium pneumaticum Staley $1968,1940$.

The new species of Prosthecomicrobium is described below.

Prosthecomicrobium hirschii sp. nov. Prosthecomicrobium hirschii (hirsch'i.i. N.L. gen. hirschii named in honor of Peter Hirsch, an indefatigable general microbiologist who has contributed greatly to our understanding of budding bacteria) strains are unicellular, gram-negative bacteria having numerous prosthecae. The prosthecae may be short (i.e., less than $1 \mu \mathrm{m}$ long) or long (i.e., more than $2 \mu \mathrm{m}$ long). Cells are coccobacillary and measure about 0.8 to 1.2 by 1.0 to 2.0 $\mu \mathrm{m}$. Cells reproduce by budding from one pole of a mother cell. Daughter buds may mature to form either large or short prosthecae or both, regardless of the appendage length of the

TABLE 2. Utilization of carbon sources by Ancalomicrobium and Prosthecomicrobium strains

\begin{tabular}{|c|c|c|c|c|c|c|c|c|c|c|c|c|}
\hline \multirow{2}{*}{ Carbon source } & \multicolumn{7}{|c|}{ P. hirschii strains } & \multirow{2}{*}{$\begin{array}{c}P . \\
\text { enhydrum } \\
9^{\mathrm{T}}\end{array}$} & \multirow{2}{*}{$\begin{array}{c}P . \\
\text { pneumaticum } \\
3^{\mathrm{T}}\end{array}$} & \multirow{2}{*}{$\begin{array}{l}\text { P. litoralum } \\
524-16^{\mathrm{T}}\end{array}$} & \multicolumn{2}{|c|}{$\begin{array}{l}\text { A. adetum } \\
\text { strains }\end{array}$} \\
\hline & 6 & 7 & 10 & 11 & 12 & 15 & $16^{\mathrm{T}}$ & & & & $8^{T}$ & 18 \\
\hline Xylose & + & + & + & + & + & + & + & + & + & + & + & - \\
\hline Arabinose & + & + & + & + & + & + & + & + & + & + & + & + \\
\hline Ribose & + & + & + & + & + & + & + & + & + & + & + & + \\
\hline Glucose & + & + & + & + & + & + & + & + & + & + & + & + \\
\hline Fructose & + & + & + & + & + & + & + & + & + & + & + & + \\
\hline Mannose & + & + & + & + & + & + & + & + & + & + & + & + \\
\hline Galactose & + & + & + & + & + & + & + & + & + & + & + & + \\
\hline Lyxose & + & + & + & + & + & + & + & + & + & $\mathrm{NT}^{a}$ & + & + \\
\hline Maltose & - & - & - & - & - & - & - & + & + & + & + & + \\
\hline Cellobiose & - & - & - & - & - & - & - & + & + & + & + & + \\
\hline Melibiose & - & - & - & - & - & - & - & - & + & - & - & - \\
\hline Lactose & - & - & - & - & - & - & - & + & + & + & + & + \\
\hline Trehalose & - & - & - & - & - & - & - & + & + & + & + & + \\
\hline Raffinose & - & - & - & - & - & - & - & - & - & - & - & - \\
\hline Meletzitose & - & - & - & - & - & - & - & - & + & NT & - & - \\
\hline Fucose & + & + & + & + & + & + & + & + & + & + & + & + \\
\hline Rhamnose & - & - & $?$ & - & - & - & - & + & + & + & + & + \\
\hline Methanol & + & + & + & + & + & + & + & - & - & NT & - & - \\
\hline Ethanol & + & + & + & + & + & + & + & - & - & NT & - & - \\
\hline Mannitol & - & - & $?$ & - & - & - & - & $?$ & + & + & + & - \\
\hline Sorbitol & - & - & - & - & - & - & - & - & + & + & + & - \\
\hline Inositol & - & - & - & - & - & - & - & - & + & NT & + & + \\
\hline Glycerol & + & + & + & + & + & + & + & $?$ & + & + & + & + \\
\hline Glucosamine & - & - & - & - & - & - & - & + & + & NT & + & + \\
\hline Formate & + & + & + & + & + & + & + & - & - & NT & - & - \\
\hline Acetate & + & + & + & + & + & + & + & + & + & + & + & + \\
\hline Pyruvate & + & + & + & + & + & + & + & + & - & + & + & + \\
\hline Propionate & + & + & + & + & + & + & + & - & - & - & + & - \\
\hline$\beta$-Hydroxybutyrate & + & + & + & + & + & + & + & + & + & + & + & + \\
\hline Valerate & + & + & + & + & + & + & + & - & - & NT & + & - \\
\hline Caproate & + & + & + & + & + & + & + & - & - & NT & - & - \\
\hline Malate & + & + & + & + & + & + & + & + & - & + & + & + \\
\hline
\end{tabular}

\footnotetext{
${ }^{a}$ NT, Not tested.
} 
mother cell. Cells may be motile by single polar to subpolar flagella. Gas vacuoles have not been detected. Sugars and organic acids are used as carbon sources for growth. In addition, methanol and ethanol can be used as carbon sources. Catalase and oxidase positive. Biotin, nicotinic acid, pantothenate, and thiamine are required for growth. Strains are mesophilic and have been isolated from freshwater habitats. Colonies are circular in form and umbonate in elevation, have entire margins, and are pink in color. The guanine-plus-cytosine content ranges from 67.9 to $69.9 \mathrm{~mol} \%$ (buoyant density method). The type strain is strain 16 (ATCC 27832).

The life cycle of this new species is complex. It is evident from slide culture studies that either a short- or longappendaged cell can serve as a mother cell. Furthermore, a short- or long-appendaged mother cell can give rise to a short- or long-appendaged daughter cell. However, once a cell has matured, its cell morphology appears to be fixed for its lifetime. Although a mother cell of either cell type can give rise to a daughter cell of any cell type, there is no random switch from one cell type to another. Instead, a cell type appears to persist for several generations. The most likely explanation for the shift in cell types is that it is a response to a change in environmental conditions. It was beyond the scope of this study to determine what those conditions might be. However, it is of interest that some authors have discussed the effect of increasing nutrients on determining whether some unidentified strains of Ancalomicrobium have short- or long-appendaged cells (12). These authors concluded that short-appendaged cells are produced at high concentrations of nutrients, whereas long-appendaged cells are produced at low nutrient concentrations. Another factor that may be important is oxygen concentration, because at high nutrient concentrations reduced oxygen concentrations occur during active growth. Regardless of the explanation, it seems that these investigators were studying either $P$. hirschii or a similar species rather than $A$. adetum, whose appendage length is typically long under normal conditions favorable for growth. It will be of interest to learn what factor(s) controls appendage length in $P$. hirschii because this discovery may prove important in ascertaining the function of prosthecae for these bacteria.

\section{ACKNOWLEDGMENTS}

This research was supported in part by grant GB-30313 from the National Science Foundation.

I thank Joe Dalmasso, Fred Palmer, and Jeannette von Weber for expert technical assistance. In addition, some strains of $P$. hirschii were provided by John Babinchak and Patricia Stanley.

\section{LITERATURE CITED}

1. Bauld, J., and J. T. Staley. 1983. Prosthecomicrobium litoralum, a new species from marine habitats. Int. J. Syst. Bacteriol. 33:613-617.

2. Hugh, R., and E. Leifson. 1953. The taxonomic significance of fermentative versus oxidative metabolism of carbohydrates by various gram-negative bacteria. J. Bacteriol. 66:24-26.

3. Matches, J. R., and J. Liston. 1973. Temperature-gradient incubator for the growth and clostridia. Can. J. Microbiol. 19:1161-1165.

4. Moore, R. L., and J. T. Staley. 1976. Deoxyribonucleic acid homology of Prosthecomicrobium and Ancalomicrobium strains. Int. J. Syst. Bacteriol. 26:283-285.

5. Staley, J. T. 1968. Prosthecomicrobium and Ancalomicrobium: new prosthecate freshwater bacteria. J. Bacteriol. 95:19211942.

6. Staley, J. T. 1973 . Budding bacteria of the Pasteuria-Blastobacter group. Can. J. Microbiol. 19:609-614.

7. Staley, J. T. 1973. Budding and prosthecate bacteria, p. 25-45. In I. Laskin and H. A. Lechevalier (ed.), Handbook of microbiology, vol. 1. Chemical Rubber Co. Press, Cleveland, Ohio.

8. Staley, J. T. 1981. The genera Prosthecomicrobium and Ancalomicrobium, p. 456. In M. P. Starr, H. Stolp, H. G. Truper, A. Balows, and H. G. Schlegel (ed.), The prokaryotes. SpringerVerlag, Berlin.

9. Staley, J. T., P. Hirsch, and J. M. Schmidt. 1981. Introduction to the budding and/or appendaged bacteria, p. 451-455. In M. P. Starr, H. Stolp, H. G. Trüper, A. Balows, and H. G. Schlegel (ed.), The prokaryotes. Springer-Verlag, Berlin.

10. Staley, J. T., and M. Mandel. 1973. Deoxyribonucleic acid base composition of Prosthecomicrobium and Ancalomicrobium strains. Int. J. Syst. Bacteriol. 23:271.

11. Vasilyeva, L. V., and N. T. Lafitskaya. 1976. Assignment of Agrobacterium polyspheroidum to the genus Prosthecomicrobium polyspheroidum comb. nov. Izv. Akad. Nauk SSSR Ser. Biol. (English Translation) 6:768-772.

12. Whittenbury, R., and C. S. Dow. 1977. Morphogenesis and differentiation in Rhodomicrobium vannielii and other budding and prosthecate bacteria. Bacteriol. Rev. 41:754-808. 